Lucrările Seminarului Geografic Dimitrie Cantemir

Vol. 45, October 2017, pp. 15-32

http://dx.doi.org/10.15551/lsgdc.v45i0.02

\title{
Opportunities of using the analytic hierarchy process method in geographic research. An application of the AHP on the deforestation problem in Romania
}

\author{
Andra-Cosmina Albulescu ${ }^{1}$, Ionuț Minea ${ }^{1}$, Daniela Larion ${ }^{1}$
}

${ }^{1}$ Alexandru Ioan Cuza University of Iasi, Romania

To cite this article: Albulescu, A.-C., Minea, I. \& Larion, D. (2017). Opportunities of using the analytic hierarchy process method in geographic research. An application of the AHP on the deforestation problem in Romania. Lucrările Seminarului Geografic Dimitrie Cantemir, Vol. 45, pp. 15-32. DOI: $10.15551 /$ lsgdc.v45i0.02

To link to this article: http://dx.doi.org/10.15551/lsgdc.v45i0.02 


\title{
OPPORTUNITIES OF USING THE ANALYTIC HIERARCHY PROCESS METHOD IN GEOGRAPHIC RESEARCH. AN APPLICATION OF THE AHP ON THE DEFORESTATION PROBLEM IN ROMANIA
}

\author{
Andra-Cosmina Albulescu', Ionuț Minea ${ }^{1}$, Daniela Larion' ${ }^{1}$
}

\begin{abstract}
The value of geographic research consists in its desiderata to understand, improve and protect its object of study and in its capacity to constantly expand its horizons by developing new methods or integrating the ones that are commonly used in other fields of research. The AHP is a multicriteria decision-making method tangentially used in Geography, especially regarding risk assessments and site suitability studies. This paper aims to reveal the opportunities of using the AHP in geographic research providing a compelling example of an application of this method in a geographic context. The AHP application focuses on the deforestation problem in Romania, evaluating it in four counties (Alba, Gorj, Maramureș and Suceava) with respect to five factors - the deforested area, the deforestation rate, the regeneration works, the GDP per capita and the population density. Ensuring a better understanding of the method's implementation, the example helps to illustrate the contribution of the AHP in solving geographic matters. The integration of the AHP as a research tool in this field is discussed in correlation with its advantages and disadvantages. The bias induced by the subjective evaluations of the decision maker is balanced by the inclusion of both quantitative and qualitative aspects and by the consistency checking mechanism. This makes the AHP a complete aggregation method that provides reliable results that can be effectively used in the pursuit of sustainable development, social innovation and increasing territorial resilience.
\end{abstract}

Keywords: Analytic Hierarchy Process, AHP, geographic research, multi-criteria decision making method

\section{Introduction}

The AHP is one of the most effective and appreciated multi-criteria decision making methods. It was developed by Thomas Saaty and refined over the years by many experts in the field of decision making. Its continuous improvement made it applicable in a variety of scientific and organizational fields. In Geography, the method was used especially regarding site suitability studies and risk assessments, but the opportunities of its application in this field are of a wider range.

The basic mechanism of the AHP is composed of a hierarchical structure that organizes the importance of the considered elements. Each element is compared with the others through a series of pairwise comparisons and the results of these comparisons are

1 “Al. I. Cuza” University of Iași, Faculty of Geography and Geology, Department of Geography, Bd.Carol I 20A, 700505, Iaşi, Romania, cosminaalbulescu@yahoo.com 
illustrated by numbers that define whether one element is more important than another or not and to what extent. This means that the operations and the outcome of the AHP rely on the expertise of the decision maker. Also, the method includes a consistency checking mechanism that ensures the reliability of the results by identifying possible errors of judgment.

Being dependent on the verity of the decision maker's judgments, the AHP tends to be biased. However, this drawback is balanced by the fact that the method includes both tangible and intangible aspects (Saaty, 2008) and by the previously mentioned consistency checking mechanism.

The AHP is a highly intuitive method that requires medium level knowledge to interpret its results. It offers a clear view of the problem by decomposing it into subsystems that can be individually analyzed and managed. These subsystems are organized hierarchically, making the entire framework easy to understand and use.

\section{General implementation of the AHP}

The hierarchical structure generated by the AHP is a multilevel one, with the decision problem formulated as a goal on the first level (level 0). The second level (level 1) includes the criteria/factors that are taken into consideration in evaluating the suitability of the alternatives/choices/options that belong to the next level (level 2). An additional level of subcriteria may be added to increase the accuracy of the outcome, resulting in a 4-level structure. Each level may comprise both objective and subjective aspects of the decision.

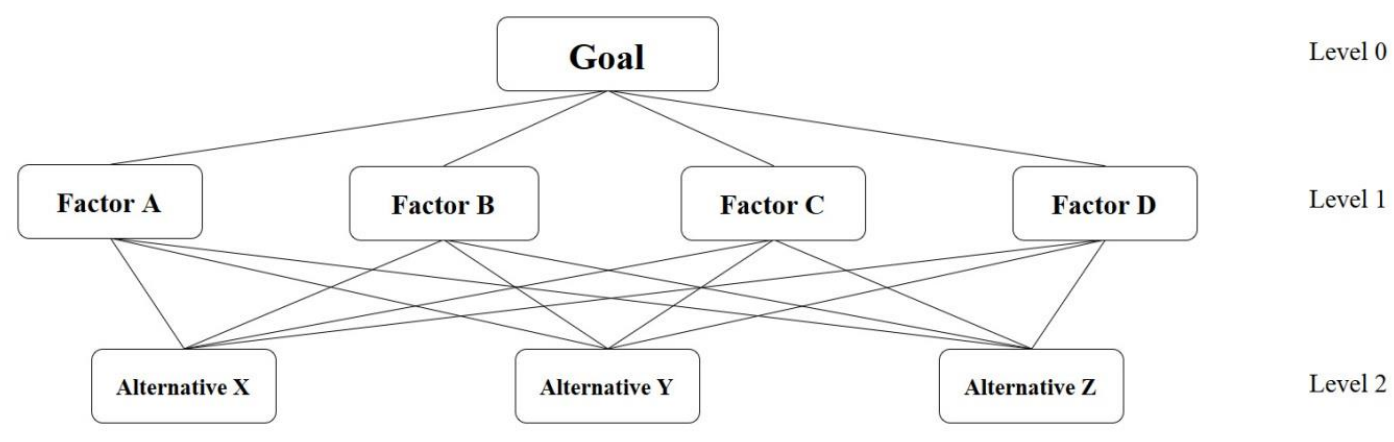

Figure 1. A hierarchical structure example

The evaluation of these elements is made by applying the technique of pairwise comparisons. The experience of the decision maker is used in order to assess which element is more suitable in comparison with another one regarding a certain factor. To achieve this, the decision maker uses a priority scale of absolute numbers (Table 1) that measures both the intangible (qualitative) and the tangible (quantitative) elements. (Saaty, 2008) 
Table 1. The fundamental scale of absolute numbers (Saaty, 2008)

\begin{tabular}{|c|c|c|}
\hline $\begin{array}{l}\text { Intensity of } \\
\text { importance }\end{array}$ & Definition & Explanation \\
\hline 1 & Equal importance & Two activities contribute equally to the objective \\
\hline 2 & Weak or slight & \\
\hline 3 & Moderate importance & $\begin{array}{l}\text { Experience and judgment slightly favour one } \\
\text { activity over another }\end{array}$ \\
\hline 4 & Moderate plus & \\
\hline 5 & Strong importance & $\begin{array}{l}\text { Experience and judgement strongly favour one } \\
\text { activity over another }\end{array}$ \\
\hline 6 & Strong plus & \\
\hline 7 & $\begin{array}{l}\text { Very strong or demonstrated } \\
\text { importance }\end{array}$ & $\begin{array}{l}\text { An activity is favoured very strongly over } \\
\text { another; its dominance demonstrated in practice }\end{array}$ \\
\hline 8 & Very, very strong & \\
\hline 9 & Extreme importance & $\begin{array}{l}\text { The evidence favouring one activity over } \\
\text { another is of the highest possible order of } \\
\text { affirmation }\end{array}$ \\
\hline $\begin{array}{l}\text { Reciprocals } \\
\text { of above }\end{array}$ & $\begin{array}{l}\text { If activity } i \text { has one of the above } \\
\text { non-zero numbers assigned to it } \\
\text { when compared with activity } j \text {, } \\
\text { then } j \text { has the reciprocal value } \\
\text { when compared with } i\end{array}$ & A reasonable assumption \\
\hline $1.1-1.9$ & If the activities are very close & $\begin{array}{l}\text { May be difficult to assign the best value but } \\
\text { when compared with other contrasting activities } \\
\text { the size of the small numbers would not be too } \\
\text { noticeable, yet they can still indicate the relative } \\
\text { importance of the activities }\end{array}$ \\
\hline
\end{tabular}

The implementation of the AHP takes place from top to bottom, starting with the first level (level 0) and continuing to the last one. In order to solve a decision problem using the AHP method, these subsequent steps must be followed:

1. Clearly define the decision problem and identify the information regarding it.

2. Generate a multilevel structure including the goal, the factors taken into consideration and the alternatives.

3. Organize the pairwise comparisons of the factors in a matrix and compute the priority vector.

4. For each factor, organize the pairwise comparisons of the alternatives in a matrix and compute the priority vector.

5. Rank the alternatives using the priority vectors previously computed.

6. Check the consistency of the results.

For a decision problem structured using four factors named A, B, C, D and three alternatives named X, Y, Z ( Figure 1), it is required to generate a matrix of $m \mathrm{x} m$ elements for the factors and $m$ matrices of $n \times n$ elements for the alternatives' scores, $m$ being the number of factors and $n$ the number of alternatives considered.

The priority scale and the expert's judgment are used in order to make the pairwise comparisons that build the factors' matrix. Each element of the $m \times \mathrm{x} m$ matrix is a number from $1 / 9$ to 9 which specifies which factor is more important compared to another and to what 
extent. Supposing we organize the pairwise comparisons of the factors in a matrix called $F$ (Table 2), each element of $F$ indicates the importance of the $i$ th factor compared to the $j$ th factor. If the $i$ th factor is more important than the $j$ th factor then $F_{i j}>1$, otherwise $F_{i j}<1$. The reciprocal value of $F_{i j}$ is obtained by dividing 1 by the value of $F_{i j}$ :

$$
F_{j i}=\frac{1}{F_{i j}}
$$

The number of pairwise comparisons that need to be made for the matrix is equal to $\frac{m(m-1)}{2}$, but the computation of the reciprocal value of a specific element using the previous formula reduces the time needed to build the matrix. The entries of the matrix follow the constraints that if $i=j, F_{i j}=1$ and that $F_{i j} \cdot F_{j i}=1$.

\begin{tabular}{c|cccc}
\multicolumn{5}{|c}{ Table 2 - F matrix } \\
& $\mathrm{A}$ & $\mathrm{B}$ & $\mathrm{C}$ & $\mathrm{D}$ \\
\hline $\mathrm{A}$ & 1 & $\mathrm{~F}_{12}$ & $\mathrm{~F}_{13}$ & $\mathrm{~F}_{14}$ \\
$\mathrm{~B}$ & $1 / \mathrm{F}_{12}$ & 1 & $\mathrm{~F}_{23}$ & $\mathrm{~F}_{24}$ \\
$\mathrm{C}$ & $1 / \mathrm{F}_{13}$ & $1 / \mathrm{F}_{23}$ & 1 & $\mathrm{~F}_{34}$ \\
$\mathrm{D}$ & $1 / \mathrm{F}_{14}$ & $1 / \mathrm{F}_{24}$ & $1 / \mathrm{F}_{34}$ & 1
\end{tabular}

After the completion of the $F$ matrix with the numbers of the priority scale and their reciprocal values, the matrix must be normalized. This operation implies that each element of the matrix will be divided by the sum of its column:

$$
F N_{i j}=\frac{F_{i j}}{\sum_{l=1}^{m} F_{l j}}
$$

The normalized matrix $F N$ is used to compute the normalized eigenvector which is called a priority vector. It includes the weights of the factors, meaning the importance of each factor with respect to the goal. The factor with the highest weight is the most important. The priority vector $W F$ is obtained by computing the arithmetic average of each line of the normalized matrix $F N$.

$$
W F_{i}=\frac{\sum_{l=1}^{m} F N_{i l}}{m}
$$

The next step consists of the computation of the alternatives' scores by creating $m$ matrices of $n \times n$ elements. Each factor will be assigned a $n \times n$ matrix of the alternatives' scores. Thus, each entry of the matrices will show the score of the $i$ th alternative compared to the $j$ th alternative regarding a certain factor, meaning the extent to which an alternative is better than the other concerning a certain factor. The matrices are created by following the steps explained for the matrix of factors.

Each matrix of the alternatives' scores will be used to compute its own priority vector. In the end, these priority vectors which illustrate the suitability of each alternative regarding a certain factor will be organized in a score matrix with $n$ lines and $m$ columns. Supposing the score matrix for the analyzed example is called $S$ and the priority vectors are called $P_{1}, P_{2}, \ldots$, 
$P_{m}$, each of the columns of the $S$ matrix comprises the priority vectors for the $i$ th factor, meaning that the first column includes the alternatives' scores regarding the first factor and so on. By way of explanation, the $S_{i j}$ entry represents the score of the $i$ th alternative regarding the jth factor.

$$
S=\left[P_{1}, \ldots, P_{m}\right]
$$

Subsequently, the final score of each option is computed as the sum of the products between the weight of a certain factor and the alternative's score regarding that factor. In other words, the simple operation of multiplying the final matrix of the alternatives' scores by the vector of factors' weights is implemented. The results can be organized in a vector of final scores $(F S)$.

$$
F S=W F \cdot S
$$

The final scores of the alternatives must be ordered in decreasing order, the first alternative being the most suitable one with respect to the goal considering the given factors. The ideal form to represent these results is obtained by dividing each final score by the largest of them. Consequently, the best alternative is made the ideal one in relation to the others, showing their proportionate values. (Saaty, 2008)

\section{Consistency checking}

The AHP method includes a useful mechanism of consistency checking that helps to reduce the bias of the decision maker and to detect and correct the errors that may occur. As the AHP applications may include a large number of factors and/or alternatives, the risk of inconsistency increases.

A typical case example of consistency is that if factor $\mathrm{A}$ is more important than factor $\mathrm{B}(\mathrm{A}>\mathrm{B})$ and factor $\mathrm{B}$ is more important than factor $\mathrm{C}(\mathrm{B}>\mathrm{C})$, then factor $\mathrm{A}$ is more important than factor $\mathrm{C}(\mathrm{A}>\mathrm{C})$. The inconsistency appears if factor $\mathrm{A}$ is less important than factor $\mathrm{C}(\mathrm{A}$ $<\mathrm{C})$. In order to identify this type of judgment errors a simple algorithm may be applied.

The algorithm works with three variables that need to be computed by the decision maker and with one index that has fixed values for a specific number of elements. The eigenvalue $(x)$, the Consistency Index (CI) and the Consistency Ratio (CR) need to be computed, while the Random Consistency Index (RI) is predetermined for specific numbers of elements. All of these values need to be computed for all the non-normalized matrices previously created and for the score matrix of $m \times n$ elements.

The eigenvalue $(x)$ is the sum of the products between each of the priority vector's elements and the specific column's sum of the corresponding non-normalized matrix:

$$
x=\sum_{i=1}^{m} W F_{i} \cdot \sum_{j=1}^{m} F_{j i}
$$


Afterwards, the CI is computed using the following formula:

$$
C I=\frac{x-m}{m-1}
$$

The RI has fixed values for specific numbers of elements. These values were obtained by Saaty (1987) as he randomly generated matrices using the designated priority scale and verifying their consistency. (Table 3)

Table 3. The Random Consistency Index for specific values (after Saaty, 1987)

\begin{tabular}{|c|c|c|c|c|c|c|c|c|c|}
\hline $\mathbf{m}$ & 2 & 3 & 4 & 5 & 6 & 7 & 8 & 9 & 10 \\
\hline RI & 0 & 0.58 & 0.90 & 1.12 & 1.24 & 1.32 & 1.41 & 1.45 & 1.49 \\
\hline
\end{tabular}

The CR is computed by dividing the CI by the RI. A perfect consistent judgment would result in a null CI, but more permissive consistency thresholds may be taken into account. Saaty (1987) states that the CR must be lower than 0.1 or $10 \%$ in order to satisfy the condition of consistency. Nevertheless, adjustments regarding the value of the consistency threshold may be made if the decision maker considers them useful.

$$
C R=\frac{C I}{R I}
$$

If the judgments regarding all of the matrices are consistent, the results are considered reliable, otherwise the incorrect set of judgment related to a certain matrix needs to be revised.

The final CR for the global score matrix is computed as a fraction that has the sum of the products between the factors' weights ( $W F$ vector) and the specific CI for that matrix in the numerator and the sum between the factors' weights and the specific RI for that matrix in the denominator.

$$
\text { Final } C R=\frac{\sum_{i=1}^{m+1} W F_{i} \cdot C I_{i}}{\sum_{i=1}^{m+1} W F_{i} \cdot R I_{i}}
$$

\section{Case Study: The deforestation problem in Romania's counties}

The application of the AHP method in a geographic context focuses on the deforestation problem in Romania, the goal being formulated as "stopping deforestation in Romania". Deforestation is one of the most stringent issues that threaten the environment of this country. In 2016, Romania's forests covered about $26.86 \%$ of its surface, meaning 6404400 ha or $64044 \mathrm{~km}^{2}$. Despite the fact that Romania had a formal forest-related outreach and communication strategy, the total public expenditure relating to forest and other wooded land was lower than 10 euro/year/ha in 2013. Furthermore, approximately $86 \%$ of Romania's forests were covered by Forest Management Plans in 2010, but only $4.1 \%$ of the forest area were undisturbed by man in 2015. (State of Europe's Forests, 2015)

The direct causes of deforestation and forests' degradation are the expansion of farming land, logging, overgrazing, fires, mining activities, urbanization, industrialization or infrastructure development, military or tourism related activities. Also, overpopulation, poverty, the debt burden, land rights, land tenure and the uneven distribution of land and other 
resources, the tendency to undervalue forests associated with corruption and different political interest are linked to the deforestation problem. (Chakravarty S., Ghosh S.K., Suresh C.P., Dey A.N., Shukla G., 2012)

The consequences of this matter are severe and they have environmental, social and economic dimensions. Deforestation leads to an increase of the flood risk, water and soil loss, climate changes, habitat loss and decreased biodiversity. In the long term, deforestation negatively affects the quality of the human life, triggering natural processes that challenge the resilience of the human communities.

Lacking the adequate laws and infrastructure to protect the forests, Romanian authorities are currently unable to address the problem on a national level. However, local mitigation actions can significantly contribute to scale down and even eradicate the deforestation matter, protect the environment and reduce the environmental and economic risks associated with deforestation.

In order to mitigate this problem, one has to identify the places where it has the biggest impact. Consequently, urgent action must be taken in those specific places. The AHP method helps to identify these strategic places using a series of criteria (factors) and the specific mathematical implementation previously presented. In this context, the alternatives that must be evaluated with respect to the considered criteria are four of Romania's counties.

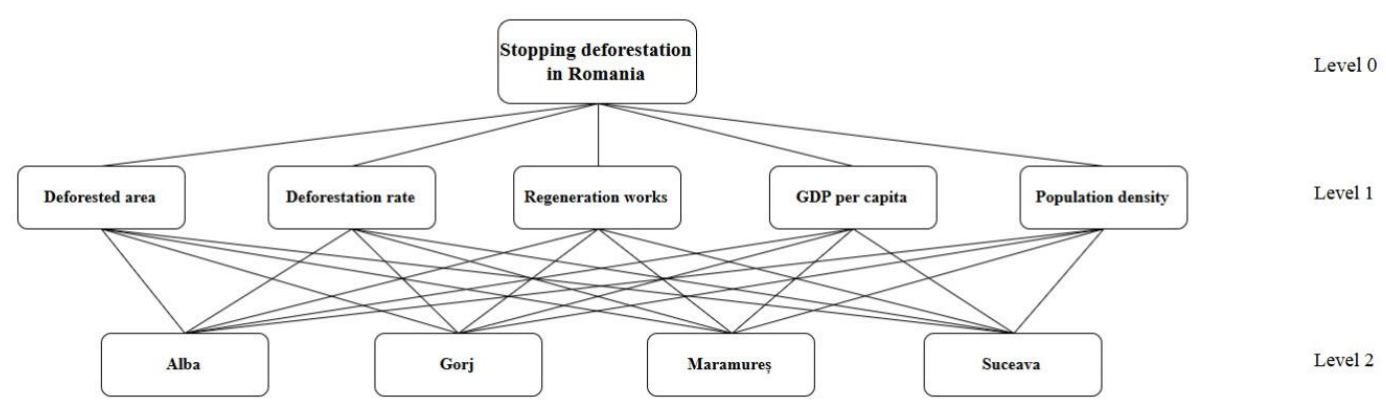

Figure 2. The hierarchical structure regarding the deforestation problem in Romania

The following AHP implementation takes into consideration five factors that are highly relevant to the deforestation problem: the deforested area for the 1990-2016 period, the deforestation rate for the same period of time, the regeneration works that took place in 2016, the GDP per and the population density for 2014. Three of these factors are directly related to the deforestation problem, while the other two factors describe the social and the economic background that is likely to influence the issue. (Figure 2)

The alternatives consist of four counties (Alba, Gorj, Maramureș and Suceava) that were selected based on their high ranks regarding the deforested area and the deforestation rate. All of these counties are characterized by a diversity of geographic features, presenting both mountainous and hill areas, a well developed hydrographic network and climatic conditions influenced by the terrain's elevation and ensuring a wide range of land uses. These features favour the development of both deciduous and coniferous forests and it can be observed that they occupy more than one third of the total surface in all of the selected counties. (Figure 3 and Table 4) 


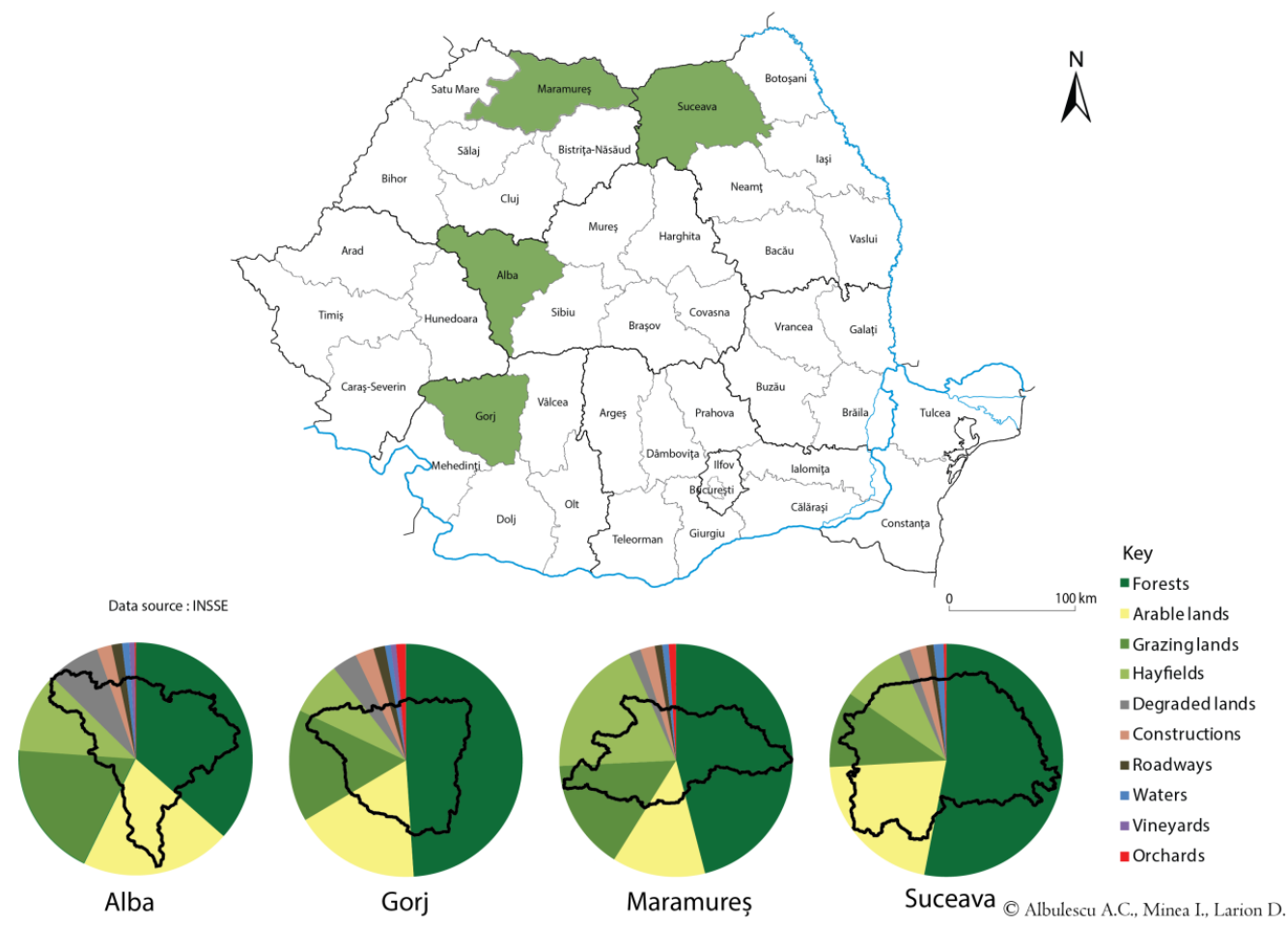

Figure 3 - The alternatives' location and land use

Table 4. The alternatives' land use (\%)

\begin{tabular}{ccccccccccc}
\hline County & Forests & $\begin{array}{c}\text { Arable } \\
\text { lands }\end{array}$ & $\begin{array}{c}\text { Grazing } \\
\text { lands }\end{array}$ & Hayfields & $\begin{array}{c}\text { Degraded } \\
\text { lands }\end{array}$ & Constructions & Roadways & Waters & Vineyards & Orchards \\
\hline Alba & 36.50 & 20.75 & 18.87 & 11.25 & 7.23 & 2.04 & 1.45 & 1.01 & 0.75 & 0.16 \\
Gorj & 48.92 & 17.54 & 15.57 & 7.44 & 3.47 & 2.59 & 1.59 & 0.80 & 0.75 & 1.33 \\
Maramures & 46.00 & 12.86 & 15.37 & 19.20 & 1.63 & 2.03 & 1.01 & 0.85 & 0.04 & 1.00 \\
Suceava & 53.03 & 21.04 & 10.58 & 8.67 & 1.65 & 2.27 & 0.97 & 1.43 & $\begin{array}{r}\text { unavailable } \\
\text { data }\end{array}$ & 0.35 \\
\hline
\end{tabular}

At the same time, the environmental attributes of these counties are premises of the economic development and the wellbeing of the human communities. The GDP per capita data indicate that the level of economic development of the selected counties is medium (Alba, Gorj and Maramureş) and low in Suceava. Additionally, the population density data suggest that the four counties have medium to low values of this indicator, mainly because of the mountainous landforms.

Legal deforestation actions may be based on the fact that new lands need to enter the economic circuit by changing their specific use and forest products need to be exploited to increase profits. On the other hand, the illegal deforestation actions that may be induced by a high level of poverty in some rural areas are poorly monitored and there are no data concerning them. The uncertainty regarding the illegal deforestation makes the situation even harder to be dealt with, this being one of the reasons why bottom-up strategies may be more effective in the pursuit of stopping deforestation in Romania. Nonetheless, both bottom-up and top-down 
mitigation projects are required in order to eradicate illegal and irrational deforestation; knowledge of the strategic places that need intervention with priority being the starting point of the mentioned desideratum.

In order to obtain more suggestive results, the priority scale used for this example was reduced to the odd numbers from 1 to 9 and their reciprocal values. The reciprocal values are expressed in decimal form instead of the fraction form in the interest of simplified calculations. (Table 5)

Table 5. The simplified priority scale including the reciprocal values in fraction and decimal form

\begin{tabular}{cccc}
\hline Value of $\boldsymbol{F}_{i j}$ & Interpretation & $\begin{array}{c}\text { The fraction form of } \\
\text { the reciprocal value }\end{array}$ & $\begin{array}{c}\text { The decimal form } \\
\text { of the reciprocal } \\
\text { value }\end{array}$ \\
\hline 1 & $i$ and $j$ are equally important & 1 & 1 \\
3 & $i$ is slightly more important than $j$ & $1 / 3$ & 0.33 \\
5 & $i$ is more important than $j$ & $1 / 5$ & 0.20 \\
7 & $i$ is strongly more important than $j$ & $1 / 7$ & 0.14 \\
9 & $i$ is absolutely more important than & $1 / 9$ & 0.11 \\
\hline
\end{tabular}

The first step of the AHP implementation consists of the weighting operation by which specific weight (importance) is attributed to each factor. Firstly, the factors' matrix is generated using pairwise comparisons and the priority scale (Table 6). After the factors' matrix has been normalized, the arithmetic average of each line is computed in order to obtain the normalized eigenvector. This is the priority vector that includes the factors' weights. (Table 7)

The validation of the results implies that the consistency of the emitted judgments must be checked and that the Consistency Ratio (CR) must be lower than 0.1 . The eigenvalue (x) was computed as 5.37, resulting in a CI of 0.09 . As the number of elements taken into consideration is 5 , the RI is 1.12 . The result obtained by dividing the CI by the RI is 0.083 , meaning that inconsistency of the judgment is tolerable.

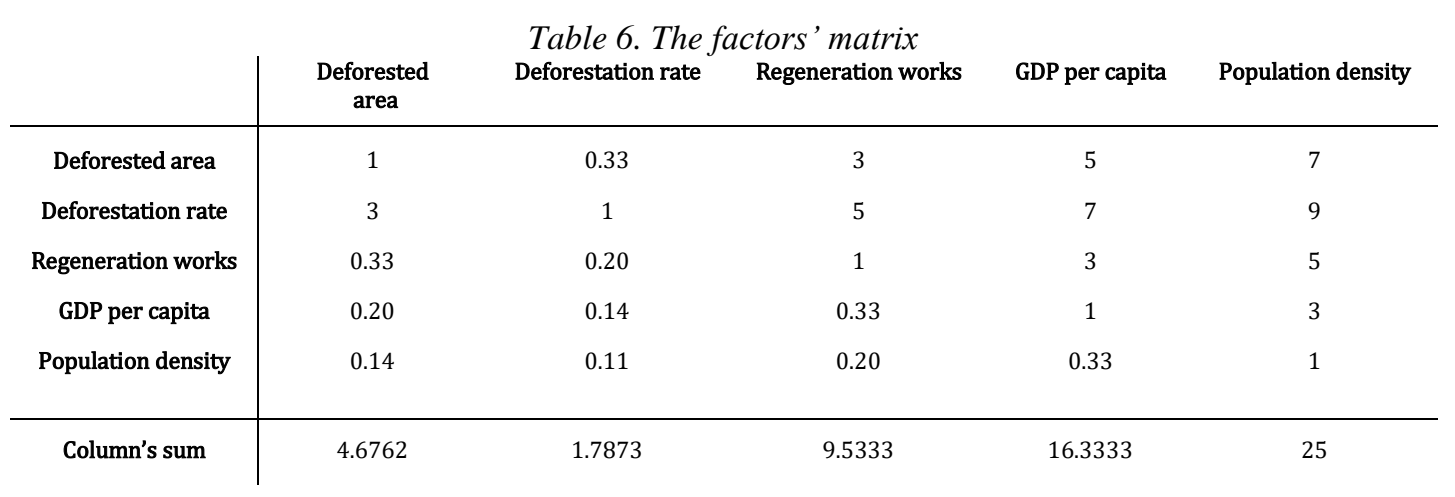


Table 7. The normalized factors' matrix and the factors' weights vector

\begin{tabular}{c|cccccc|c} 
& $\begin{array}{c}\text { Deforested } \\
\text { area }\end{array}$ & $\begin{array}{c}\text { Deforestation } \\
\text { rate }\end{array}$ & $\begin{array}{c}\text { Regeneration } \\
\text { works }\end{array}$ & $\begin{array}{c}\text { GDP } \\
\text { per capita }\end{array}$ & $\begin{array}{c}\text { Population } \\
\text { density }\end{array}$ & $\begin{array}{c}\text { Factor's } \\
\text { weight }\end{array}$ \\
\hline Deforested area & 0.21 & 0.19 & 0.31 & 0.31 & 0.28 & 0.260232 \\
$\begin{array}{c}\text { Deforestation } \\
\text { rate }\end{array}$ & 0.64 & 0.56 & 0.52 & 0.43 & 0.36 & 0.502820 \\
$\begin{array}{c}\text { Regeneration } \\
\text { works }\end{array}$ & 0.07 & 0.11 & 0.10 & 0.18 & 0.20 & 0.134351 \\
$\begin{array}{c}\text { GDP per capita } \\
\text { Population density }\end{array}$ & 0.04 & 0.08 & 0.03 & 0.06 & 0.12 & 0.067778 \\
& 0.03 & 0.06 & 0.02 & 0.02 & 0.04 & 0.034821
\end{tabular}

Figure 4 illustrates that the most important factor is the deforestation rate, with a weight of 0.5028 or $50.28 \%$. It is followed by the deforested area $(26.02 \%)$, the regeneration works $(13.43 \%)$, the GDP per capita $(6.77 \%)$ and the population density $(3.48 \%)$. This means that the factors related directly to the deforestation issue are more important that the ones that offer information about the social and economic background of the selected counties.

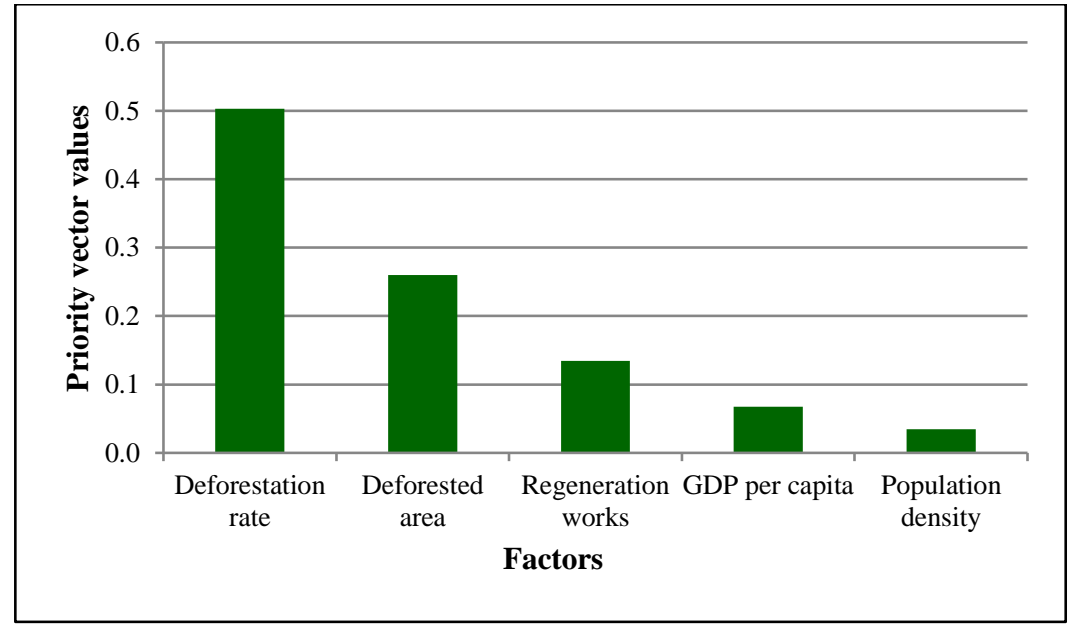

Figure 4. The ranking of factors' weights

After the weights of the factors have been computed, the same steps must be followed to obtain the score of each alternative regarding each of the factors. In this case, 5 matrices of 4 x 4 elements will be generated, normalized and used for the computation of the priority vectors that include the scores of the alternatives regarding the factors. The processed data used to make pairwise comparisons with the alternatives can be examined in Table 8.

Table 8. The data used to formulate judgments and create the matrices of scores

\begin{tabular}{|c|c|c|c|c|c|}
\hline Counties & $\begin{array}{c}\text { Deforested } \\
\text { area } \\
\text { 1990-2016 } \\
\text { (thousands Ha) }\end{array}$ & $\begin{array}{c}\text { Deforestation } \\
\text { rate } \\
1990-2016 \\
(\%)\end{array}$ & $\begin{array}{c}\text { Regeneration } \\
\text { works } \\
2016 \\
\text { (Ha) }\end{array}$ & $\begin{array}{c}\text { GDP per } \\
\text { capita } \\
2014 \\
\text { (Lei) }\end{array}$ & $\begin{array}{c}\text { Population } \\
\text { density } \\
2014 \\
(\text { people per } \\
\text { km²) }^{2} \text { ) } \\
\end{array}$ \\
\hline Alba & 4.30 & 0.08 & 292.00 & 28726.01 & 61.40 \\
\hline
\end{tabular}




\begin{tabular}{cccccc}
\hline Gorj & 5.80 & 0.09 & 144.00 & 26985.02 & 66.03 \\
Maramureș & 4.70 & 0.07 & 433.00 & 20645.00 & 83.70 \\
Suceava & 3.40 & 0.03 & 2130.00 & 16533.87 & 86.61 \\
\hline
\end{tabular}

The matrices of alternatives' scores regarding each of the five factors are presented below, together with their normalized versions and with the corresponding priority vector. (Table 9 to Table 13) It can be observed that the AHP includes contrasting factors, the higher values of the deforested area, the deforestation rate and the population density suggesting a higher risk of deforestation, while the higher values of the regeneration works and the GDP per capita indicate a lower risk. This divergence doesn't affect the reliability of the results, as the factors' weights have a regulatory role. Thus, the best alternative is not the one that has the highest scores with respect to all the factors, but the one that obtains a trade-off among the factors. (Saaty, 2008)

Table 9. The matrices of alternatives' scores regarding the deforested area

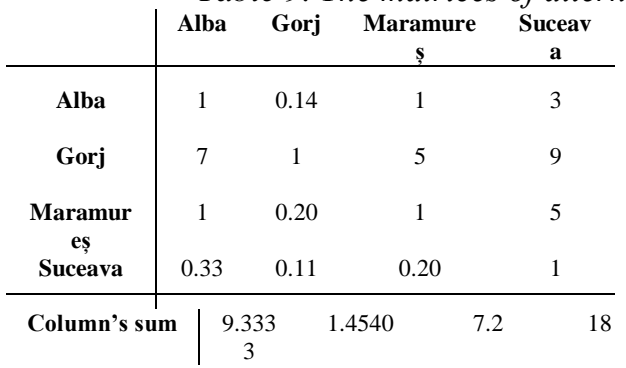

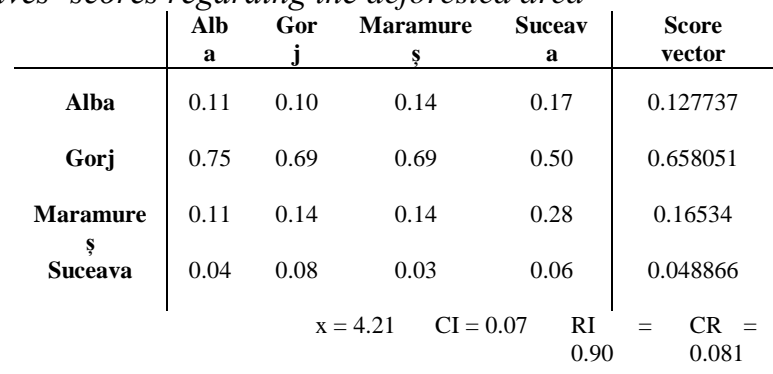

Table 10. The matrices of alternatives' scores regarding the deforestation rate

\begin{tabular}{|c|c|c|c|c|c|c|c|c|c|c|}
\hline & Alba & Gorj & Maramureș & Suceava & & Alba & Gorj & Maramureș & Suceava & $\begin{array}{c}\text { Score } \\
\text { vector }\end{array}$ \\
\hline Alba & 1 & 1 & 3 & 7 & Alba & 0.40 & 0.41 & 0.42 & 0.29 & 0.381152 \\
\hline Gorj & 1 & 1 & 3 & 9 & Gorj & 0.40 & 0.41 & 0.42 & 0.38 & 0.401985 \\
\hline Maramureş & 0.33 & 0.33 & 1 & 7 & Maramureş & 0.13 & 0.14 & 0.14 & 0.29 & 0.175662 \\
\hline Suceava & 0.14 & 0.11 & 0.14 & 1 & Suceava & 0.06 & 0.05 & 0.02 & 0.04 & 0.041204 \\
\hline Column's sum & 2.4762 & 2.4444 & 7.1429 & 24 & & & $\mathrm{x}=4.17$ & $\mathrm{CI}=0.05$ & $\mathrm{RI}=0.90$ & $\mathrm{CR}=0.062$ \\
\hline
\end{tabular}

Table 11. The matrices of alternatives' scores regarding the regeneration works

\begin{tabular}{|c|c|c|c|c|c|c|c|c|c|c|}
\hline & Alba & $\begin{array}{c}\text { Gor } \\
\text { j }\end{array}$ & $\begin{array}{c}\text { Maramure } \\
\mathbf{s} \\
\end{array}$ & $\begin{array}{c}\text { Suceav } \\
\text { a } \\
\end{array}$ & & $\begin{array}{c}\text { Alb } \\
\text { a }\end{array}$ & Gorj & $\begin{array}{c}\text { Maramure } \\
\$ \\
\end{array}$ & $\begin{array}{c}\text { Suceav } \\
\text { a } \\
\end{array}$ & $\begin{array}{l}\text { Score } \\
\text { vector }\end{array}$ \\
\hline Alba & 1 & 1 & 1 & 0.14 & Alba & $\begin{array}{c}0.1 \\
0\end{array}$ & 0.07 & 0.14 & 0.10 & $\begin{array}{c}0.10151 \\
1\end{array}$ \\
\hline Gorj & 1 & 1 & 0.33 & 0.11 & Gorj & $\begin{array}{c}0.1 \\
0\end{array}$ & 0.07 & 0.05 & 0.08 & $\begin{array}{c}0.07332 \\
5\end{array}$ \\
\hline $\begin{array}{c}\text { Maramure } \\
s ̧\end{array}$ & 1 & 3 & 1 & 0.20 & $\begin{array}{c}\text { Maramure } \\
\text { ş }\end{array}$ & $\begin{array}{c}0.1 \\
0\end{array}$ & 0.21 & 0.14 & 0.14 & $\begin{array}{c}0.14705 \\
0\end{array}$ \\
\hline Suceava & 7 & 9 & 5 & 1 & Suceava & $\begin{array}{c}0.7 \\
0\end{array}$ & 0.64 & 0.68 & 0.69 & $\begin{array}{c}0.67810 \\
9\end{array}$ \\
\hline Column's sum & 10 & 14 & 7.3333 & 1.4540 & & & $\begin{array}{l}x= \\
4.10\end{array}$ & $\mathrm{CI}=0.03$ & $\mathrm{RI}=0.90$ & $\mathrm{CR}=0.039$ \\
\hline
\end{tabular}


Table 12. The matrices of alternatives' scores regarding the GDP per capita

\begin{tabular}{c|cccc} 
& Alba & Gorj & $\begin{array}{c}\text { Maramure } \\
\text { s }\end{array}$ & $\begin{array}{c}\text { Suceav } \\
\mathbf{a}\end{array}$ \\
\hline Alba & 1 & 1 & 7 & 9 \\
Gorj & 1 & 1 & 5 & 9 \\
$\begin{array}{c}\text { Maramure } \\
\text { s }\end{array}$ & 0.14 & 0.20 & 1 & 3 \\
Suceava & 0.11 & 0.11 & 0.33 & 1 \\
\hline Column's sum & 2.2540 & $\begin{array}{c}2.311 \\
1\end{array}$ & 13.3333 & 22
\end{tabular}

\begin{tabular}{|c|c|c|c|c|c|}
\hline & $\begin{array}{c}\text { Alb } \\
\text { a }\end{array}$ & Gorj & $\begin{array}{c}\text { Maramure } \\
\text { ș }\end{array}$ & $\begin{array}{c}\text { Suceav } \\
\mathrm{a}\end{array}$ & $\begin{array}{l}\text { Score } \\
\text { vector }\end{array}$ \\
\hline Alba & $\begin{array}{c}0.4 \\
4\end{array}$ & 0.43 & 0.53 & 0.41 & $\begin{array}{c}0.45261 \\
1\end{array}$ \\
\hline Gorj & $\begin{array}{c}0.4 \\
4\end{array}$ & 0.43 & 0.38 & 0.41 & $\begin{array}{c}0.41511 \\
0\end{array}$ \\
\hline Maramure & 0.0 & 0.09 & 0.08 & 0.14 & 0.09032 \\
\hline \multirow[t]{2}{*}{ Suceava } & $\begin{array}{c}6 \\
0.0 \\
5\end{array}$ & 0.05 & 0.03 & 0.05 & $\begin{array}{c}1 \\
0.04195 \\
7\end{array}$ \\
\hline & & $\begin{array}{l}x \\
4.10\end{array}=$ & $\mathrm{CI}=0.03$ & $\mathrm{RI}=0.90$ & $\begin{array}{l}\mathrm{CR} \\
0.039\end{array}=$ \\
\hline
\end{tabular}

Table 13. The matrices of alternatives' scores regarding the population density

\begin{tabular}{c|cccc} 
& Alba & Gorj & Maramureş & Suceava \\
\hline Alba & 1 & 1 & 0.14 & 0.11 \\
Gorj & 1 & 1 & 0.14 & 0.14 \\
Maramureş & 7 & 7 & 1 & 1 \\
Suceava & 9 & 7 & 1 & 1 \\
\hline Column's sum & 18 & 16 & 2.2857 & 2.2540
\end{tabular}

\begin{tabular}{c|cccc|c} 
& Alba & Gorj & Maramures & Suceava & $\begin{array}{c}\text { Score } \\
\text { vector }\end{array}$ \\
\hline Alba & 0.0 & 0.06 & 0.06 & 0.05 & 0.057463 \\
Gorj & 6 & & & & \\
Maramures & 0.0 & 0.06 & 0.06 & 0.06 & 0.060984 \\
Suceava & 0.3 & 0.44 & 0.44 & 0.44 & 0.426887 \\
& $\begin{array}{c}0.5 \\
0\end{array}$ & 0.44 & 0.44 & 0.44 & 0.454665 \\
& & $\mathrm{x}=4.01$ & $\mathrm{CI}=0.003$ & $\mathrm{RI}=0.90$ & $\mathrm{CR}=0.003$
\end{tabular}

The matrix of the alternatives' final scores comprises the score vectors from the matrices previously computed and it is organized as a structure of four lines, one for each of the alternatives and five columns, one for each of the factors. (Table 14) The scores are multiplied by the weight value of the corresponding factor. Finally, the sum of the multiplication's results is computed and the alternatives are ranked according to this value.

(Figure 5)

Table 14. The matrix of the alternatives' final scores

\begin{tabular}{|c|c|c|c|c|c|}
\hline & $\begin{array}{c}\text { Deforested } \\
\text { area }\end{array}$ & Deforestation rate & Regeneration works & GDP per capita & Population density \\
\hline Alba & 0.12774 & 0.38115 & 0.10151 & 0.45261 & 0.05746 \\
\hline Gorj & 0.65805 & 0.40199 & 0.07333 & 0.41511 & 0.06098 \\
\hline Maramureș & 0.16534 & 0.17566 & 0.14705 & 0.09032 & 0.42689 \\
\hline \multirow[t]{2}{*}{ Suceava } & 0.04887 & 0.04120 & 0.67811 & 0.04196 & 0.45466 \\
\hline & * & * & $*$ & $*$ & $*$ \\
\hline $\begin{array}{l}\text { Factors' } \\
\text { weights }\end{array}$ & 0.260232 & 0.502820 & 0.134351 & 0.067778 & 0.034821 \\
\hline
\end{tabular}

\begin{tabular}{c|ccccc|c} 
& $\begin{array}{c}\text { Deforested } \\
\text { area }\end{array}$ & Deforestation rate & Regeneration works & GDP per capita & Population density & Final scores \\
\hline Alba & 0.03324 & 0.19165 & 0.01364 & 0.03068 & 0.00200 & 0.27121 \\
Gorj & 0.17125 & 0.20213 & 0.00985 & 0.02814 & 0.00212 & 0.41348 \\
Maramureş & 0.04303 & 0.08833 & 0.01976 & 0.00612 & 0.01486 & 0.17210 \\
Suceava & 0.01272 & 0.02072 & 0.09110 & 0.00284 & 0.01583 & 0.14321
\end{tabular}




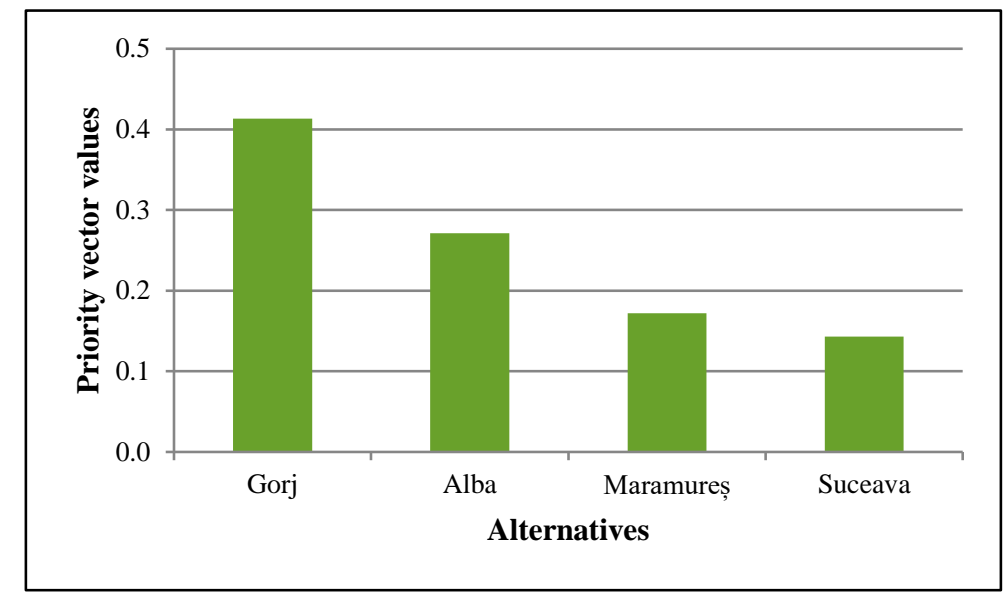

Figure 5. The alternatives' ranking

The final consistency checking operation is obtained by multiplying each factor's weight with the CI of its corresponding matrix and computing the sum of these products. In order to avoid errors, it is established that the weight for the initial matrix of the factors' weight is equal to 1 . The same operations are applied for the RI. The final CR is obtained by dividing the sum of the CI and the factors' weights by the sum of the RI and the factors' weights. As the final $\mathrm{CR}$ is 0.07 , the consistency condition is fulfilled and the results are reliable. (Table 15)

\begin{tabular}{|c|c|c|c|c|c|}
\hline \multicolumn{6}{|c|}{ Table 15. The final consistency checking } \\
\hline & $\begin{array}{l}\text { Factors' } \\
\text { weights }\end{array}$ & CI & RI & $\begin{array}{c}\text { Factors' weights } \\
\text { CI }\end{array}$ & $\begin{array}{c}\text { Factors' weights · } \\
\text { RI }\end{array}$ \\
\hline & 1 & 0.0935 & 1.1200 & 0.0935 & 1.1200 \\
\hline Deforested area & 0.2602 & 0.0730 & 0.9000 & 0.0190 & 0.2342 \\
\hline Deforestation rate & 0.5028 & 0.0567 & 0.9000 & 0.0285 & 0.4525 \\
\hline $\begin{array}{l}\text { Regeneration } \\
\text { works }\end{array}$ & 0.1344 & 0.0353 & 0.9000 & 0.0047 & 0.1209 \\
\hline GDP per capita & 0.0678 & 0.0356 & 0.9000 & 0.0024 & 0.0610 \\
\hline \multirow[t]{3}{*}{ Population density } & 0.0348 & 0.0035 & 0.9000 & 0.0001 & 0.0313 \\
\hline & & & $\Sigma$ & 0.148271 & 2.020000 \\
\hline & & & $\begin{array}{c}\text { Final } \\
\text { CR }\end{array}$ & 0.073402 & \\
\hline
\end{tabular}

As Figure 5 suggests, the county where the deforestation problem has the most powerful impact is Gorj. This county is characterized by the largest values of the deforested area and the deforestation rate and the lowest value of the regeneration works, implying an alarming situation. Therefore, prioritized mitigation measures must be taken by the local and the national authorities in Gorj. 
Table 16. Alternatives' final scores

\begin{tabular}{ccccc}
\hline Alternative & Final score & Final score (\%) & Idealised final score & Idealised final score (\%) \\
\hline Gorj & 0.41348 & 41.35 & 1 & 100 \\
Alba & 0.27121 & 27.12 & 0.65591 & 65.59 \\
Maramureș & 0.17210 & 17.21 & 0.41621 & 41.62 \\
Suceava & 0.14321 & 14.32 & 0.34636 & 34.64 \\
\hline
\end{tabular}

The second alternative is Alba, followed by Maramureș and Suceava. The issue of deforestation must be addressed in these counties too, as they rank in the top four of the most deforested counties of Romania. The idealised form of the results is presented in Table 16. The idealised form of the results indicates that Alba is affected by deforestation as much as $65.59 \%$ comparing to Gorj, while Maramureș and Suceava are affected by $41.62 \%$, respectively $34.64 \%$ as much as the ideal alternative.

The deforestation mitigation actions need to be based on cooperation among the government, the local authorities, stakeholders and communities. These actions include measures that aim to extend the protected areas, to improve the standard of management of the protected areas, to increase the perceived and actual values of forests and the area of forest plantations. Moreover, the promotion of sustainable development must be supported by strengthening actions of the government and non-government institutions and policies. Increased investments in research and education, together with policy, legislative and regulatory measures-enforcement and compliance may also contribute to reduce deforestation and protect the forest environment. (Chakravarty S., Ghosh S.K., Suresh C.P., Dey A.N., Shukla G., 2012)

\section{Applications of the AHP in geographic research}

The AHP method may be applied in a variety of fields (Table 17), the most cited being public administration, human resources, industry, transport, politics, military, law system, education and marketing. (Saaty, 2008) The AHP is used to compare impacts of alternative policies generated by physical assessment tools, modelling tools and environmental appraised tools. Also, it can support the evaluations of alternative policies projects in Socioeconomic Impact Assessment and Strategic Environmental Assessment. (Milovanovic A., Mitricevic M., Mijalkovic A., 2012)

Vargas (1990) states that the practical applications of the AHP are related to Resource Allocation, Strategic Planning and Risk Management. In addition, environmental impact assessments were conducted using this method. (Ramanathan, 2001)

In Geography, the method is used mainly for risk assessments and suitability site studies. The previous example proves that the AHP constitutes an effective research tool that may be used to solve a decision making problem that relies on geographic information and data. Examples of other AHP applications in this field may be examined in Table 18. 
Table 17. Applications of the AHP method (after Saaty, 2008)

\begin{tabular}{|c|c|}
\hline Field & Applications \\
\hline $\begin{array}{l}\text { Public } \\
\text { administration }\end{array}$ & $\begin{array}{ll}- & \text { resources allocation } \\
\text { - } & \text { prioritising objectives across requirements in limited } \\
& \text { resource environments } \\
\text { - } & \text { defining at risk elements } \\
\text { - } & \text { setting the standards for future strategic plans } \\
\text { - } & \text { refining analytical frameworks } \\
\text { - } & \text { benefit-cost and benefit-risk analysis }\end{array}$ \\
\hline Human resources & - $\quad$ hiring decisions \\
\hline Industry & $\begin{array}{l}\text { - choosing the type of oil drilling platform needed to be } \\
\text { built (North Atlantic, 1987) }\end{array}$ \\
\hline Transport & $\begin{array}{l}\text { - choosing the entertainment system vendor for a fleet of } \\
\text { airplanes (British Airways, 1998) }\end{array}$ \\
\hline Politics & $\begin{array}{l}\text { - } \quad \text { the admission of China into WTO } \\
\text { - } \quad \text { choosing strategies to solve the South African conflict and } \\
\text { mitigate the apartheid policy (Institute of Strategic } \\
\text { Studies, Pretoria, 1986) }\end{array}$ \\
\hline Military & $\begin{array}{ll}\text { - } & \text { decision making regarding the National Missile Defence } \\
\text { - } & \text { military personnel promotions }\end{array}$ \\
\hline Law system & $\begin{array}{l}\text { - decision making regarding the US vs. China conflict in } \\
\text { the intellectual property rights (1995) }\end{array}$ \\
\hline Education & - $\quad$ student admissions \\
\hline Marketing & $\begin{array}{l}\text { - establishing priorities for criteria that improve customer } \\
\text { satisfaction (Ford Motor Company, 1999) }\end{array}$ \\
\hline Sports & 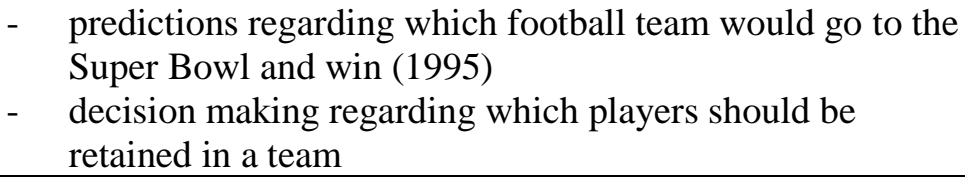 \\
\hline
\end{tabular}

Table 18. Possible applications of the AHP method in the field of Geography

\begin{tabular}{lll}
\hline \multicolumn{1}{c}{ Field } & \multicolumn{1}{c}{ Applications } \\
\hline Geomorphology & - & $\begin{array}{l}\text { risk assessments regarding landslides, mudflows, lahars } \\
\text { determining the importance of triggering and preparatory } \\
\text { factors for specific landslides }\end{array}$ \\
\hline Climatology & - & $\begin{array}{l}\text { decision making regarding the location of aeolian or solar } \\
\text { power plants } \\
\text { determining the importance of factors that cause different } \\
\text { climatic phenomena }\end{array}$ \\
\hline Hydrology & - & $\begin{array}{l}\text { flood risk assessments } \\
\text { decision making regarding the location of hydroelectric or } \\
\text { tidal power plants } \\
\text { decision making regarding the impacts of spatial planning on } \\
\text { drainage basins }\end{array}$ \\
\hline Biogeography & - & $\begin{array}{l}\text { decision making regarding the impacts of certain economic } \\
\text { activities on specific biomes, habitats, plant of animal species }\end{array}$ \\
\hline
\end{tabular}




\begin{tabular}{lll}
\hline & & $\begin{array}{l}\text { decision making regarding the protection measures required } \\
\text { in natural reserves }\end{array}$ \\
\hline Pedology & - & $\begin{array}{l}\text { decision making regarding the improvement or maintenance } \\
\text { of the soil's physical and chemical parameters } \\
\text { decision making regarding the strategies that aim to reduce } \\
\text { soil erosion }\end{array}$ \\
\hline $\begin{array}{l}\text { Political } \\
\text { Geography }\end{array}$ & - & $\begin{array}{l}\text { solving different types of internal and international conflicts } \\
\text { decision making regarding the structure of different political } \\
\text { organizations }\end{array}$ \\
\hline Population & - & decision making regarding the relocation of disaster victims \\
Geography & - & decision making regarding pro-natal or anti-natal policies \\
\hline Settlement & - & $\begin{array}{l}\text { decision making regarding the location of refugees camps, } \\
\text { emergency services, new urban or rural settlements, urban }\end{array}$ \\
Geography & & $\begin{array}{l}\text { zones } \\
\text { decision making regarding the development of infrastructure }\end{array}$ \\
\hline $\begin{array}{l}\text { Economic } \\
\text { Geography }\end{array}$ & - & $\begin{array}{l}\text { decision making regarding the location of different business } \\
\text { and activities } \\
\text { decision making regarding the development of tourism } \\
\text { decision making regarding travelling itineraries }\end{array}$ \\
\hline $\begin{array}{l}\text { Cultural } \\
\text { geography }\end{array}$ & - & $\begin{array}{l}\text { decision making regarding the location of a cultural event } \\
\text { decision making regarding the promotion of specific cultural } \\
\text { features }\end{array}$ \\
\hline
\end{tabular}

The AHP can be integrated as a geographic research tool by combining it with GIS. The outcomes consist of complex risk assessments and risk related maps that may be included in local planning and emergency plans, contributing to sustainable development. A compelling example is represented by the floodplain risk assessment conducted by Siddayao G.P., Valdez S.E., Fernandez P.L. (2014). Furthermore, the AHP can be combined with SWOT analysis, resulting in the A'WOT method used in prioritising natural resource management strategies at the Finnish Forest and Park Service. (Kangas J., Pesonen M., Kurttila M., Kajanus M., 2001) Currently, the A'WOT is used in practical strategic planning.

To integrate decision making projects in a geographic context is of crucial importance, as the relationships between the factors and alternatives that are considered influence the hierarchical structure of the problem. The probability of errors increases with the omission of information regarding the interactions between the constituent elements, putting in jeopardy the suitability of the decisions. By applying the AHP method, geographic research merges with decision making concepts, creating an integrating framework suitable for manifold opportunities.

The strengths of the AHP are numerous and have been cited by many specialists: Ramanathan (2001) outlines its flexibility, intuitive appeal and consistency mechanism, Macharis et al. (2004) appreciate the fact that it decomposes problems into their constituent parts, Saaty (1987) praises it for its ability to provide an overall view of the problem and Zahir (1999) comments on the possibility to use the AHP method for group decision making by computing the geometric mean of the individual pairwise comparisons. Furthermore, the method has no limitations regarding the time scale or the geographic coverage. (Milovanovic A., Mitricevic M., Mijalkovic A., 2012)

These features recommend the AHP as an effective geographic research method, as geographers are familiar with the pairwise comparison concept, commonly comparing 
elements on different scales in order to analyse and classify them. The method allows geographers to focus on the details of the problem without losing sight of the bigger picture. At the same time, by covering the environmental, economic and social dimensions of the problem, the AHP offers a holistic approach and acts like an integrating tool that accurately illustrates the characteristics of reality.

Taking into consideration both objective and subjective evaluations (Milovanovic A., Mitricevic M., Mijalkovic A., 2012) and working with both tangible and intangible elements (Saaty, 2008), the AHP reduces the bias in decision making and ensures the reliability of the results. Moreover, the AHP may take into consideration contrasting factors (Milovanovic A., Mitricevic M., Mijalkovic A., 2012), helping to deal with the diversity of geographic reality.

Another strength of this method lies its ability to model situations of uncertainty and risks by deriving scales to measure aspects that are not commonly quantified. (Millet, I.; Wedley, W.C., 2002) This means that the AHP may be used in risk assessments, to generate and evaluate hazard related scenarios or even to make predictions regarding different phenomena.

Nonetheless, the AHP has shortcomings that can interfere with the purposes of geographic research. One of the biggest problems regarding this method is the reversal of ranks, which may occur if the decision maker introduces a new alternative that is similar to a pre-existing one. This issue was analyzed by Belton and Gear (1983) and it can be avoided by establishing a correct interpretation of the factors' weights or by considering the AHP structure a network rather than a hierarchical construction as Harker and Vargas proposed (1987). Moreover, Triantaphyllou (2001) proved that the problem of rank reversal can be completely eliminated if the multiplicative version of the AHP (MAHP) is used.

Being a complete aggregation method of the additive type, the AHP tends to compensate between the higher and the lower scores obtained by the alternatives regarding different criteria. (Milovanovic A., Mitricevic M., Mijalkovic A., 2012) This leads to the omission of important details, causing the results to become inaccurate and hindering geographic research.

Another drawback of the AHP consists in the number of pairwise comparisons that need to be made by the decision maker. This number increases in a quadratic manner, making the task a time consuming one. (Macharis C., Springael J., De Bycker K., Verbeke A., 2004) For example, when comparing 4 alternatives regarding 5 criteria, 10 comparisons are needed to compute the weight vector and 30 pairwise comparisons are needed to build the score matrices.

Criticism of the AHP comprises an analysis of the artificial limitations imposed by the 9-point scale. If two alternatives are more important than a third one to the same extent, inconsistency problems may arise. (Macharis C., Springael J., De Bycker K., Verbeke A., 2004) To simplify the evaluation task and reduce the time associated with it other evaluation scales may be used, one of the most cited ones being the geometric scale. (Ramanathan, 2001; Lootsma, 1999)

\section{Conclusions}

In this paper, some of the most important characteristics of the AHP method were outlined and an explanation of its general implementation was presented. An example of its application regarding the deforestation problem in Romania was used in order to prove that 
the AHP can be effectively used in geographic research and further examples of applications in the Geography field were introduced. The integration of the AHP in geographic research was discussed from the point of view of its strengths and shortcomings, offering a better understanding of the flexible framework of the method.

For the application concerning the deforestation problem in Romania, the relevant data were illustrated using tables, graphics and cartographic representations and the mathematical aspects of the AHP were explained in detail. The results fulfil the condition of consistency, proving to be reliable and useful in the pursuit of assessing the deforestation problem and its mitigation.

By presenting the AHP as a geographic research tool, it is hoped that this field will benefit from the integration of the method and that the opportunities associated with its implementation will improve both the scientific field and the quality of human life.

\section{References}

1. Belton V., Gear T., 1983. On a short-coming of Saaty's method of abalytic hierachies. Omega $11,228-230$

2. Chakravarty S., Ghosh S.K., Suresh C.P., Dey A.N., Shukla G., 2012. Deforestation: Causes, Effects and Control Strategies. Global Perspectives on Sustainable Forest Management

3. Food and Agriculture Organization of the United Nations, 2015. State of Europe's Forests

4. Harker P.T., Vargas L.G., 1987. The theory of ration scale estimation: Saaty's analytic hierarchy process. Management Science 33 (11), 1383-1403.

5. Kangas J., Pesonen M., Kurttila M., Kajanus M., 2001. A'WOT: Integrating the AHP with SWOT analysis. 6th ISAHP Proceedings, Switzerland

6. Lootsma F., 1999. Multi-criteria Decision Analysis via Ratio and Difference Judgement

7. Macharis C., Springael J., De Bycker K., Verbeke A., 2004. PROMETHEE and AHP: The design of operational synergies in multicriteria analysis. Strengthening PROMETHEE with ideas of the AHP. Elsevier, European Journal of Operational Research 153, 307-317

8. Millet I., Wedley W.C., 2002. Modelling Risk and Uncertainty with the Analytic Hierarchy Process. Journal of Multi-Criteria Decision Analysis, 97-107.

9. Milovanovic A., Mitricevic M., Mijalkovic A., 2012. The Analytic Hierarchy Process (AHP) Application in Equipment Selection. SYMORG Symposium Proceedings, Serbia

10. Ramanathan R., 2001. A note on the use of the analytic hierarchy process for environmental impact assessment. Journal of Environmental Management 63, 27-35

11. Saaty T., 1987. The Analytic Hierarchy Process - What it is and how it is used. Mathl Modelling, Vol. 9, No. 3-5, 161-176

12. Saaty T., 2008. Decision making with the analytic hiearchy process. Int. J. Services Sciences, Vol I, No. 1, 83-98

13. Siddayao G.P., Valdez S.E., Fernandez P.L., 2014. Analytic Hierarchy Process (AHP) in Spatial Modeling for Floodplain Risk Assessment. International Journal of Machine Learning and Computing, Vol. 4, No. 5

14. Triantaphyllou E., 2001. Two New Cases of Rank Reversals when the AHP and Some of its Additive Variants are Used that do not Occur with the Multiplicative AHP. Journal of Multi-Criteria Decision Analysis 10, 11-25

15. Zahir S., 1999. Clusters in group: Decision making in the vector space formulation of the analytic hierarchy process. European Journal of Operational Research 112, 620-634 